\title{
Holy Ground of Teaching and Learning
}

\author{
KATHERINE LOW \\ Brite Divinity School, Texas Christian University (USA)
}

This brief article consists of my reflections after attending a class about teaching and learning in higher education. After shifting my assumptions from modern expectations that a "good" and systematic form of teaching can be taught, to post-modern ideas concerning rich and complex experiences, I express my new understanding of teaching and learning. Due to the complex richness of recursion and feedback loops, teaching and learning holds implications beyond the classroom into the wider world. Human capacities for play, creativity, and organization resonate with a spiritual understanding of a playful God. In this theological grounding, I conceptualize the classroom in terms of a holy place in which teachers and students playfully and reverently interact and care for one another and for the subject at hand.

\section{A Second-Order Change}

I entered a class about teaching and learning in higher education with an understanding that I could systematically learn "good" teaching. I was to enter the college classroom for the first time to teach an introductory course in religion and the Bible and eagerly anticipated learning the best method. I expected that this class would function like that of a cooking class. The recipe in my head read something like the following:

\section{A Recipe for Good Teaching}

One dedicated and learned teacher

One text-book per student

A pinch of other readings

points to taste
A batch of students

Weekly lectures

Add discussions and power- 
Mix one text-book per student in a classroom, adding a pinch of other readings into the mixture. Speak at the mixture weekly for one hour, providing it your knowledge and expertise. Let the mixture sit for a while to absorb the required knowledge. Bake the mixture at 250 degrees by giving a midterm essay test and requiring a final paper-this will solidify it and make it sturdy.

I expected that I would learn a similar recipe in this class; that teaching and learning are objects of study I could step-away from to analyze, to read what other scholars say about teaching and learning, and then write a research paper around my findings. If I just learned proper steps to take, then I would become a good teacher. I found that this is not the case. A second order change, marked by deep transformation, occurred when I realized that how I experience a modern to post-modern paradigm shift also applies to teaching and learning.

We live in complex, living and dynamic systems. Order emerges out of these systems in nonlinear ways. The same holds true for teaching and learning. How I learn as a student is not how other students learn. What works for some teachers does not work for others. Teaching and learning in such complex and ever-changing systems cannot be boiled-down to one "right" way-students and teachers make meaning for themselves, play with what is of interest to them, and provide a web of feedback loops within a community of learning. Letting go of an expectation of one right way allows for emergence of rich meaning, as Reynolds and Craven (2008) suggest, "To recover the richness that will allow self-organization and transformation to occur means that I abandon hope of finding or bringing students to some coherent, consistent, right or best understanding." In his discussion concerning curriculum, Doll (1993) contends that teaching is a "transformative process" in which "we will need to view curriculum as more than a series of contingent units - to see it as a mixed and multivariate integration of rich, open-ended experiences; as a complex mosaic ever shifting its center of attraction as we shift ours" (p. 38). This is a post-modern view of teaching and learning, one that has changed my assumptions about teaching and learning. Now, instead of thinking in terms of "right," "wrong," "best" or "worst," I consciously engage my teaching with the awareness of new possibilities while constantly revisiting my beliefs.

\section{Recursion and Feedback Loops}

Doll organizes his thoughts on post-modern education around four conceptsrichness, recursion, relations, and rigor. As part of a complex process of relationship between the field of study, student, and teacher, I most appreciate how recursion allows for richness and transformative change in teaching and learning. Doll explains recursion as a kind of looping, "thoughts on thoughts" which "distinguishes human consciousness; it is the way we make meaning" (p. 177). In this sense, it is natural for humans to revisit old ideas yet, unlike repetition, recursion leads to the conceptualization of something different while using former things and ideas. 
I have found recursion helpful in terms of the reality of the teacher's need to evaluate student work. A reciprocal, caring teacher-student relationship provides opportunities for feedback: "Feedback-regulated learning creates a recursive modification of thought and dynamic course correction . . .." (Reynolds \& Craven, 2008). The teacher remains teacher due to her or his expertise and skill, but a teacher also engages in complicated mutual relationships with students that require caring. bell hooks (2003) states, "At its best, teaching is a caring profession" (p. 86).

In terms of caring, Nell Noddings (2004) notes one of my challenges: "The teacher as one-caring and the student as cared-for both have difficulty in the matter of evaluation" (p. 193). I find evaluation difficult when I teach. But, by offering as much feedback as possible, whether through small written assignments, group dialogue, or one-on-one meetings, the teacher allows for "appropriate thought, sensitivity, and open communication" (p. 193). In this way, the teacher also remains open to feedback and recursion, as "There is always the possibility in this open and good-seeking dialogue that the one-caring will alter her own views and procedures. She is not by status or knowledge a priori right; she is just one-caring-who wants to do what is right and remains willing to explore the possibilities" (p. 124).

\section{Relation to the World}

In a post-modern world, Sharon Daloz Parks (2005) observes that "One discovers again and again that the practice of leadership occurs within a more vast, complex, and dynamic world-where knowledge is always partial and the outcomes of one's actions uncertain" (p. 56). Parks' words resonate with Lorenz's work in chaos theory, that one small change in one part of the world could have large repercussions for another part of the world. This is also called "the Butterfly Effect" in which a butterfly flapping its wings in one place can cause a tornado or another natural event in another remote part of the world. In other words, the world consists of complex causal relationships. Therefore, teaching not only stays within the classroom-students take their transformations with them into other settings and what they organize for themselves interact with others in complex causal relationships.

Because of this complexity, the classroom examines multiple viewpoints and approaches in the area of study and reflects a variety of diversity. hooks (2003) believes that "Educators who challenge themselves to teach beyond the classroom setting, to move into the world sharing knowledge, learn a diversity of styles to convey information. This is one of the most valuable skills any teacher can acquire" (p. 43). Above all, hooks stresses a need for practice as well as theory: "Education can affirm that self-esteem in black students/students of color when educators are anti-racist in word and deed" (p. 79).

hooks challenged me to think about how I might talk about racism yet do nothing about racism when I have the ability to do so. In my third tutoring session required for a course on teaching and learning, for instance, the student wanted to talk about contemporary myths surrounding biblical stories. She wanted me to choose the myths. I 
did not deal with race at all. I did not consciously think to bring-up the so-called "Curse of Ham" from Noah (Gen 9:18-29) or the existence of the institution of slavery in the Sarah and Hagar story (Gen 16, 21). Had I reflected more deeply on why I brought the themes to the third session that I did, perhaps I would have recognized my choice not to deal with racism. I could have brought this awareness to our fourth and final session together, and the student and I would have benefited from discussing it. In teaching and learning, issues of racism, classism, and sexism can be deconstructed and grappled-with if they become conscious parts of the learning community. As hooks states, "to build community requires vigilant awareness of the work we must continually do to undermine all the socialization that leads us to behave in ways that perpetuate domination" (p. 36).

\section{Spirituality and Teaching}

When I began my tutoring sessions, I listed various themes we could look at together, including the Genesis creation stories, stories of sibling rivalry, and women's roles in the Bible. We simply got to know one another during our first session; the student picked a few things of interest from the list and added some of her interests to the list as well. During our second session, I found myself engaging in pastoral care with the student (it came naturally to do so as an ordained minister), to accompany her on her journey in her relationship with God and explore how she saw the Bible fit into that journey. At one level, I was caring for the student I was tutoring, keeping her experience in mind. I believe it is important to examine who students are in the classroom in which I will teach. However, on another level, I lost sight of a balance between caring for students and caring for the subject of our tutoring sessions.

I learned after our second session that I desire to teach because of my own personal faith and understanding of how God works in the world. I consider teaching a ministry, one to which I am called out of a deep love for how I grow as a person when I discover new ideas. However, I must not lose sight of my academic discipline and field of study when I step into the classroom. In teaching, I will help the students examine biblical texts from varied perspectives, from numerous angles and through many lenses. The class, in other words, is not about individual beliefs, though beliefs may or may not be affected through engaging a learning process. The class rests within the realm of scholarship, of examining and articulating positions from within a specific area of discipline. My spirituality of teaching comes from a reverence for the subject of study, whatever it may be. In essence, a classroom becomes holy ground.

\section{Playing in Sacredness}

When introducing his concept for post-modern curriculum, Doll calls upon exploration in the "fascinating imaginative realm born of God's laughter" (p. 176). Toni Craven once noted in a class which she taught on the Book of Genesis that when God created the world, God engaged in playfulness when God formed human beings from the soil of the ground and breathed the breath of life into their nostrils (Gen 2:7). This 
playfulness remains at the core of creation. In fact, Stuart Brown (1994) notes when watching animals play that "new and exciting studies of the brain, evolution, and ethology, or animal behavior, suggest that play may be as important to life-for us and for other animals - as sleeping and dreaming" (p. 8).

I believe teaching is steeped in sacredness when it allows for imagination and play. Noddings states, "But we need balance in our instructional efforts and far greater emphasis on affect and training of the senses. That the subject matter is worth looking at and listening to, that it can be played with, that it may respond unexpectedly, are messages worth conveying to our students" (p. 146). Humans have the power to creatively organize and reorganize objects, events, and social systems. Modernity assumes a hierarchical organization within society. But, modern education ignores creative power to produce a variety of complex systems; post-modern education assumes a heterarchal organization, based on creative and organizing powers existent in all people, including students.

As all God's children, surrounded in playfulness, we are all connected through rich causal relationships. In terms of conceptualizing teaching and learning, especially in terms of theological education, in the context of community, Craven and Reynolds offer these words:

Things are not simple in theological education any longer. The process of interconnection is no longer controlled by one privileged group of individuals, even though there are discernible boundaries. Interdependence, not rugged individualism, is the model of our day. Linear, hierarchical maps of relationships fail to describe our field or its rich, multiple complexity. Consequently, hierarchy is being displaced by emergent heterarchy. And mutual causality is replacing linearity.

Learning in a post-modern world reflects emergent heterarchy, although there are limits to what the class can do. The teacher knows the limits and boundaries of the class within the teacher's respective discipline and holds the obligation to keep it within its scope. Like a kaleidoscope, a class remains dynamic and ever-changing within itself but is limited within a boundary.

When I entered college, I was drawn to the love of learning beautiful concepts and discovering inter-relatedness with the world. Like being drawn to the beautiful interacting colors of a kaleidoscope, I enjoy dialogue between movements and concepts. I still hold a passion for a playful interaction between myself, my classmates, my instructors, and the experts in my field across the globe. My excitement about teaching is a part of that playful interaction, one that will continue to change as I move about in my career, and one that I hope students enjoy as well.

Acknowledgments

This article comes out of my experience in a course taught by Sherrie Reynolds and Toni Craven, BRIT 95103: Advanced Education Research Seminar: Teaching and Learning in Higher Education, Summer 2006, at Brite Divinity School, Texas Christian University. I owe gratitude to Sherrie and Toni, and to William Doll, for their scholarship and support. 
Vignette Holy Ground

\section{References}

Brown, S. L. (1994). Animals at play. National Geographic 186(6), 2-35.

Daloz Parks, S. (2005). Leadership can be taught: A bold approach for a complex world. Boston: Harvard Business School Press.

Doll, W. (1993). A post-modern perspective on curriculum. New York: Teachers College Press.

hooks, B. (2003). Teaching community: A pedagogy of hope. New York: Routledge.

Noddings, N. (2004). Caring: A feminine approach to ethics and moral education. Berkeley: University of California Press.

Reynolds, S. and T. Craven. (forthcoming) Higher education reconceived: A geography of change. Fort Worth, TX: Texas Christian Univerisity Press.

\section{About the Author}

Katherine Low is a Candidate for the Doctor of Philosophy in Biblical Interpretation at Brite Divinity School, Texas Christian University, Fort Worth, Texas. She is currently writing her dissertation on the Book of Job, enjoying its complexities and dynamic meanings. [Email: k.b.low@tcu.edu; Website: www.katherinelow.com]

(C) Copyright 2008. The author, KATHERINE LOW, assigns to the University of Alberta and other educational and non-profit institutions a non-exclusive license to use this document for personal use and in courses of instruction provided that the article is used in full and this copyright statement is reproduced. The author also grants a non-exclusive license to the University of Alberta to publish this document in full on the World Wide Web, and for the document to be published on mirrors on the World Wide Web. Any other usage is prohibited without the express permission of the authors. 